\title{
On What Foundation is Africa Building its Science and Technology Base?: Africa's Participation in TIMSS-2003
}

\author{
Anamuah-Mensah, $\mathbf{J}^{1}$. \\ University of Education, Winneba, P. O Box 25, Winneba Ghana \\ $\&$ \\ Mereku, D. K. \\ Faculty of Science Education, University of Education,Winneba Ghana
}

\begin{abstract}
In 2003, six African countries - Ghana Egypt, Tunisia, Morocco, Botswana and South Africa - participated in an international assessment programme in science and mathematics, called the Trends in International Mathematics and Science Study (TIMSS). The study examined the performance of eighth graders in mathematics and science as well as the contextual factors that could have influenced the performance. Analyses of the data indicated that in general the African countries performed poorly. Countries in the north of Africa performed significantly better than those in sub-Saharan Africa. Generally they all performed poorly on items that involved solving non routine problems and reasoning. Examination of the context for learning science and mathematics revealed several weaknesses in the curricula of the participating African countries. It indicated that majority of the students did not have the opportunity to learn a substantial proportion of the content assessed in the TIMSS even though these were part of their intended curricula. The least use of technology (i.e. calculators and computers) in the curricula was also reported by the African countries. Recommendations are made for African governments to pay attention to the teaching of science and mathematics in the primary and secondary schools. The results of the study suggest the need to carry out an indebt examination to identify the dimensions of the problem for information that would be helpful in policy decisions to address the issue across the continent.
\end{abstract}

\section{What is TIMSS?}

TIMSS is a series of studies conducted by the International Association for the Evaluation of Educational Achievement (IEA) to examine student achievement in science and mathematics, two key curriculum areas that are fundamental to the development of technologically literate societies. From the time of its inception in 1959, IEA has conducted more than 16 crossnational studies on achievement in a number of curricular areas including mathematics and science. IEA conducted its First International Mathematics Study (FIMS) in 1964 and the First International Science Study (FISS) in 1970-71. Mathematics and science were again assessed in the Second International Mathematics Study (SIMS) and the Second International Science Study (SISS) in 1980-82 and 1983-84 respectively. From then on, IEA decided to conduct regular assessment of mathematics and science achievement every four years. Following this, a combined comparative assessment of science and mathematics, the Third International Mathematics and Science Study (TIMSS) was conducted in 1994-1995 for students at various levels of pre-tertiary education. In 1999, TIMSS (also known as TIMSS-Repeat or TIMSS-R) re-assessed grade eight students' achievement in both mathematics and science in order to measure trends in student achievement since 1995.

TIMSS-2003, re-named Trends in International Mathematics and Science Study, followed the lines of TIMSS-1999. It is the most recent in the series of IEA studies designed to measure trends in students' achievement in mathematics and science. It is a large scale study involving Years 4 and 8 students in forty-six countries. This paper examines the performance of the African countries - Botswana, Egypt, Ghana Morocco, Tunisia and South Africa - that participated in TIMSS-2003. The administration of TIMSS-2003 was carried out under the

\footnotetext{
${ }^{1}$ This was a paper presented by the authors at CODOVOST
} 
auspices of IEA. The International Study Centre (ISC) in Boston College's Lynch School of Education in USA was responsible for the design and implementation of the study. Other bodies that played significant roles in ensuring the success of the study were: IEA Data Processing Centre in Hamburg, Germany; Statistics Canada, which was responsible for collecting and evaluating the sample and helping participants to adapt the TIMSS sampling design; and Educational Testing Service, which carried out the scaling of the achievement data. IEA has begun preparations for TIMSS-2007, the fourth assessment in the framework of TIMSS.

\section{What did participation in TIMSS-2003 mean to AFRICAN COUNTRIES?}

TIMSS-2003 has provided the participating countries in Africa with the opportunity to examine students' achievement in mathematics and science using an international yardstick and to compare this to that of other countries both within and beyond the continent of Africa. It also provided rich information on the context for the teaching and learning of mathematics and science in African schools which could be used to identify strengths and weaknesses in teaching and learning of these subjects. By being participant, African countries will be able to gather information at regular intervals about what our students know and what they can do in mathematics and science. It will also enable policy makers to identify the contextual variables that can be modified to bring about improvement in the learning and teaching of science and mathematics. Such cross-cultural comparison can help to discover the characteristics including the inefficiencies of our educational systems that we fail to notice because of our familiarity with the systems.

\section{Which countries took part in TIMSS-2003?}

The forty-six countries listed below participated in TIMSS-2003; the six of them from Africa are starred.

$\begin{array}{llll}\text { Armenia } & \text { Ghana* } & \text { Lithuania } & \text { Saudi Arabia } \\ \text { Australia } & \text { Hong Kong, SAR } & \text { Macedonia, Rep. of } & \text { Scotland } \\ \text { Bahrain } & \text { Hungary } & \text { Malaysia } & \text { Serbia } \\ \text { Belgium (Flemish) } & \text { Indonesia } & \text { Moldova, Rep. of } & \text { Singapore } \\ \text { Botswana* } & \text { Iran, Islamic Rep. of } & \text { Morocco* } & \text { Slovak Republic } \\ \text { Bulgaria } & \text { Israel } & \text { Netherlands } & \text { Slovenia } \\ \text { Chile } & \text { Italy } & \text { New Zealand } & \text { South Africa* } \\ \text { Chinese Taipei } & \text { Japan } & \text { Norway } & \text { Sweden } \\ \text { Cyprus } & \text { Jordan } & \text { Palestinian, Nat'l Auth. } & \text { Tunisia* } \\ \text { Egypt* } & \text { Korea, Rep. of } & \text { Philippines } & \text { United States } \\ \text { England } & \text { Latvia } & \text { Romania } & \\ \text { Estonia } & \text { Lebanon } & \text { Russian Federation } & \end{array}$

\section{The Conceptual and Contextual Framework for TIMSS-2003}

The goal of TIMSS over the years has been to measure student achievement in mathematics and science subjects, in order to learn more about the nature and extent of achievement and the context in which it occurs. It tries to achieve this by isolating the factors directly related to student learning that can be manipulated through policy changes in, for example, allocation of school and classroom resources, curriculum and its emphasis, or instructional practices of the teachers as well as the characteristics of the students. In the studies, these broad explanatory factors underlying student achievement are classified under curriculum (Robitaille and Garden, 1996). The conceptual framework for TIMSS-2003 was therefore based on a three-strand model of the curriculum: the intended curriculum (what society would like to see taught), the implemented curriculum (what is actually taught), and the attained curriculum (what the students learn). Based on this perspective of the educational process, TIMSS assessed, through context questionnaires, factors such as national and school context, classroom characteristics, teachers, curriculum and student characteristics that are likely to influence students' learning of mathematics and the sciences. The curriculum framework used for TIMSS- 2003 has two 
organizing dimensions or aspects, a content dimension and a cognitive dimension, similar to those used in TIMSS-1995 and 1999. The content dimension defines the specific subject matter content of school mathematics and science. The cognitive dimension describes the many kinds of behaviour expected of students as they engage with the content in school mathematics and science. See Mullis, et al., (2004) and Martin, et al., (2004) for details of the frameworks.

\section{Population and Sampling Procedures}

The international desired (i.e. target) population for TIMSS-2003 consisted of all students who had had eight years of education with at least two years of instruction in the language of testing prior to the test. This was the eighth grade in most countries and is referred to as the eighthgrade population. The age range was from 13 to 18 years with a mean of 15.5 years. TIMSS2003 used standards, procedures and guidelines that ensured that country samples were of the highest quality, thus making achievement results comparable across countries. The sampling process used in selecting students in TIMSS-2003 was the same as that used in the previous TIMSS studies. The sampling plan for the selection of the participating students was developed with the help of Statistics Canada, which was also supportive in guiding the sampling process.

\section{Instruments}

The large pool of items required for a valid assessment of mathematics and science achievement based on TIMSS assessment frameworks demands that each grade eight student spends at least seven hours to answer the entire pool of test items. This time demand is not realistic as it raises issues about test reliability. To ensure that there is broad subject matter coverage without overburdening students, TIMSS used a rotated design for both the mathematics and science items. In the TIMSS framework, a design based on multiple matrix sampling technique was used to divide the item pool among a set of student booklets with each student completing one of twelve booklets containing both mathematics and science items. This means that students responded to only a subset of the larger pool of items in such a way that each item was responded to by a representative sample of students. The assignment of each student to one of the twelve test booklets was done randomly.

The test was conducted in two sessions, each session lasting 45 minutes. About 70 per cent of the test items used in the study were in multiple-choice format and accounted for about two thirds of the testing time. The remaining 30 percent were in free-response and accounted for about one-third of the testing time. The use of psychometric scaling techniques based on Item Response Theory (IRT) makes it possible for population estimates to be generated even though students do not respond to all the items or even the same items. The population estimates are obtained through the use of IRTs plausible value methodology. A comprehensive explanation of the scaling process has been given by Gonzalez, Galia and Li (2004). TIMSS-2003 used this approach to generate the overall science and mathematics scores and the scale scores for the two subjects. To obtain information on the context within which science and mathematics learning takes place, TIMSS-2003 (like TIMSS 1995 and 1999) developed a contextual framework to obtain information from curriculum specialists such as personnel from the Ministries of education of participating countries, students in participating schools, their science and mathematics teachers and their head teachers. Questionnaires were developed for this purpose.

\section{Overview of African Students' Achievement in Science and Mathematics}

In this section, the achievements of eighth graders from participating African countries in mathematics and science are compared to that of students in some of the other forty-five countries that participated in TIMSS-2003. In particular, the performance of students from the participating African countries is compared to that of countries in Asia such as Malaysia, Singapore, Japan, Chinese Taipei, Singapore and Republic of Korea that were at the same level of development as Ghana in the 1960s. Also included in the comparison is the formal colonial 
master and trading partner, England, as well as USA which has had a very good relationship with Africa and has been supporting its educational systems through the Agency for International Development (USAID). The results presented in this paper are largely tables extracted to showcase the achievements of eighth graders from the participating African since the detailed results can be obtained in Mullis, et al., (2004) and Martin, et al., (2004).

The overall performance of the students from the participating African countries on the mathematics and science tests was very low. Ghana obtained low mean scale scores of 255 and 276 in science and mathematics respectively, placing the nation second from the bottom of the overall results table (Table 1).

Table 1. The overall mean science and mathematics achievement scores

\begin{tabular}{|c|c|c|c|c|c|}
\hline Country & $\begin{array}{l}\text { Overall Mean } \\
\text { Science } \\
\text { Achievement } \\
\left(\mathrm{SE}^{*}\right)\end{array}$ & $\begin{array}{l}\text { Overall Rank } \\
\text { of country's } \\
\text { Science scale } \\
\text { score }\end{array}$ & Country & $\begin{array}{l}\text { Overall Mean } \\
\text { Mathematics } \\
\text { Achievement } \\
\text { (SE*) }\end{array}$ & $\begin{array}{l}\text { Overall Rank } \\
\text { of country's } \\
\text { Mathematics } \\
\text { scale score }\end{array}$ \\
\hline Singapore & $578(4.3)$ & 1 & Singapore & $605(3.6)$ & 1 \\
\hline Chinese & $571(3.5)$ & 3 & Chinese & $585(4.6)$ & 4 \\
\hline Taipei & & & Taipei & & \\
\hline Korea & $558(1.6)$ & 2 & Korea & $589(2.2)$ & 2 \\
\hline Japan & $552(1.7)$ & 6 & Japan & $570(2.1)$ & 5 \\
\hline England & $544(4.1)$ & $* *$ & England & $498(4.7)$ & $* *$ \\
\hline USA & $527(3.1)$ & 9 & USA & $498(4.7)$ & 15 \\
\hline Malaysia & $510(3.7)$ & 20 & Malaysia & $508(4.1)$ & 10 \\
\hline $\begin{array}{l}\text { International } \\
\text { Average }\end{array}$ & $474(0.6)$ & - & $\begin{array}{l}\text { International } \\
\text { Average }\end{array}$ & $467(0.5)$ & - \\
\hline Egypt & $421(3.9)$ & 36 & Egypt & $406(3.5)$ & 37 \\
\hline Tunisia & $404(2.1)$ & 39 & Tunisia & $410(2.2)$ & 36 \\
\hline Morocco & $396(2.5)$ & 41 & Morocco & $396(2.5)$ & 41 \\
\hline Botswana & $365(2.8)$ & 44 & Botswana & $366(2.6)$ & 43 \\
\hline Ghana & $255(5.9)$ & 45 & Ghana & $276(4.7)$ & 45 \\
\hline South Africa & $244(6.7)$ & 46 & South Africa & $264(5.5)$ & 46 \\
\hline
\end{tabular}

Compared to other African countries that took part in the study, the performance of Ghana and South Africa were the lowest (Table 1). Egypt obtained the highest mean score in science, and Tunisia obtained the highest mean score in mathematics. All the African countries in TIMSS2003 performed significantly lower than the international country mean. However, among the African countries, the North Africans performed significantly better than all the Sub-Saharan African countries. The poor performance of the African countries may call for the need to reexamine educational policies and practices in these countries.

\section{African Students' Performance against the International Benchmarks}

TIMSS-2003 mathematics and science achievement scales summarise Year 8 (JSS2) students' performance on test items designed to measure a wide range of student knowledge and understanding. Four points on each scale were identified for use as international benchmarks. The performance of all the students in all the countries that participated in TIMSS-2003 was taken into account when defining these benchmarks, which are described as follows:

Advanced International Benchmark corresponding to a scale score of 625,

High International Benchmark corresponding to a scale score of 550,

Intermediate International Benchmark corresponding to a scale score of 475 , and

$\sim \quad$ Low International Benchmark corresponding to a scale score of 400.

See Mullis, et al., (2004) and Martin, et al., (2004) for details of characteristics of the international benchmarks of science and mathematics. 
Overall, Ghana ranked $46^{\text {th }}$ on the international benchmark in science. Only $13 \%$ and $3 \%$ of Ghanaian students reached the low and intermediate international benchmarks respectively (Table 2). Over $65 \%$ of the students in sub-Saharan Africa not reaching the low international benchmark implies that majority of our students have poor knowledge of basic science and mathematics facts and have weak grasp of science and mathematics concepts as well as enquiry skills that are lower level cognitive competencies. Though the situation is not as grave in the North African States, barely half of the students are reaching the low international benchmark. It was only in Egypt that $1 \%$ of the students reached the high or advanced international benchmarks in both science and mathematics.

Table 2. Percentages of Students Reaching TIMSS-2003 International Benchmarks of Science and Mathematics Achievement in Africa and Selected Countries

\begin{tabular}{lcccccccc}
\hline & \multicolumn{3}{c}{$\begin{array}{c}\text { Percentage of students reaching international benchmark } \\
\text { Advanced }\end{array}$} & \multicolumn{2}{c}{ High } & \multicolumn{2}{c}{$\begin{array}{c}\text { Lntermediate } \\
\text { Inter }\end{array}$} \\
Countries & Science & Maths & Science & Maths & Science & Maths & Science & Maths \\
\hline Singapore & 33 & 44 & 66 & 77 & 85 & 93 & 95 & 99 \\
Chinese Taipei & 26 & 38 & 63 & 66 & 88 & 85 & 98 & 96 \\
Korea, Rep. of & 17 & 35 & 57 & 70 & 88 & 90 & 98 & 98 \\
Japan & 15 & 24 & 53 & 62 & 86 & 88 & 98 & 98 \\
Malaysia & 4 & 6 & 28 & 30 & 71 & 66 & 95 & 93 \\
England & 15 & 5 & 48 & 29 & 81 & 64 & 96 & 90 \\
United States & 11 & 7 & 41 & 41 & 75 & 75 & 93 & 93 \\
International & 6 & 6 & 25 & 24 & 54 & 51 & 78 & 75 \\
Average & & & & & & & & \\
Egypt & 1 & 1 & 10 & 6 & 33 & 24 & 59 & 52 \\
Morocco & 0 & 0 & 1 & 1 & 13 & 10 & 48 & 42 \\
Tunisia & 0 & 0 & 1 & 1 & 12 & 15 & 52 & 55 \\
Botswana & 0 & 0 & 1 & 1 & 10 & 7 & 35 & 32 \\
South Africa & 1 & 0 & 3 & 2 & 6 & 6 & 13 & 10 \\
Ghana & 0 & 0 & 0 & 0 & 3 & 2 & 13 & 9 \\
\hline
\end{tabular}

Countries such as Japan, Singapore, Malaysia, USA and England with almost all students reaching the low benchmark have educational systems that do excellent job of educating all its students. The educational system in Ghana where only 13 percent of the students reached the low benchmark does not appear to provide adequate preparation for its students. The low percentage of Ghanaian students reaching the higher benchmarks suggests the need to assist students to build a sound grounding in the mastery of basic knowledge and skills required to solve more cognitively demanding problems.

\section{Contexts for Learning Science and Mathematics in African Countries}

To provide a context for interpreting the achievement results, detailed information on students' backgrounds and attitudes towards mathematics and science, teachers' background, classroom characteristics and school contexts for learning and instruction, was gathered from the students taking part in the study. The mathematics and science teachers of these students, as well as their head teachers, were also made to provide information on the context in which mathematics and science learning was taking place in their schools. See Mullis, et al., (2004) and Martin, et al., (2004) for details of the findings. In this paper, only the findings regarding teachers' qualifications and the use of technology in the mathematics and science curriculum are discussed.

Less than $10 \%$ of the grade eight students in all the African countries except Tunisia were taught by mathematics and science teachers with a university degree or its equivalent. But the results show that most of the countries with high achievement mean scores had most of their mathematics and science teachers with at least a university degree. 
Use of Technology: Computers and calculators. Though the national curricula of some of the African countries contain policy statements about the use of computers and calculators in the science and mathematics curricula, over $85 \%$ of the teachers (except those in Tunisia) reported that computers were not available in their schools (Table 3 and 4).

Table 3. Computer use in the science class

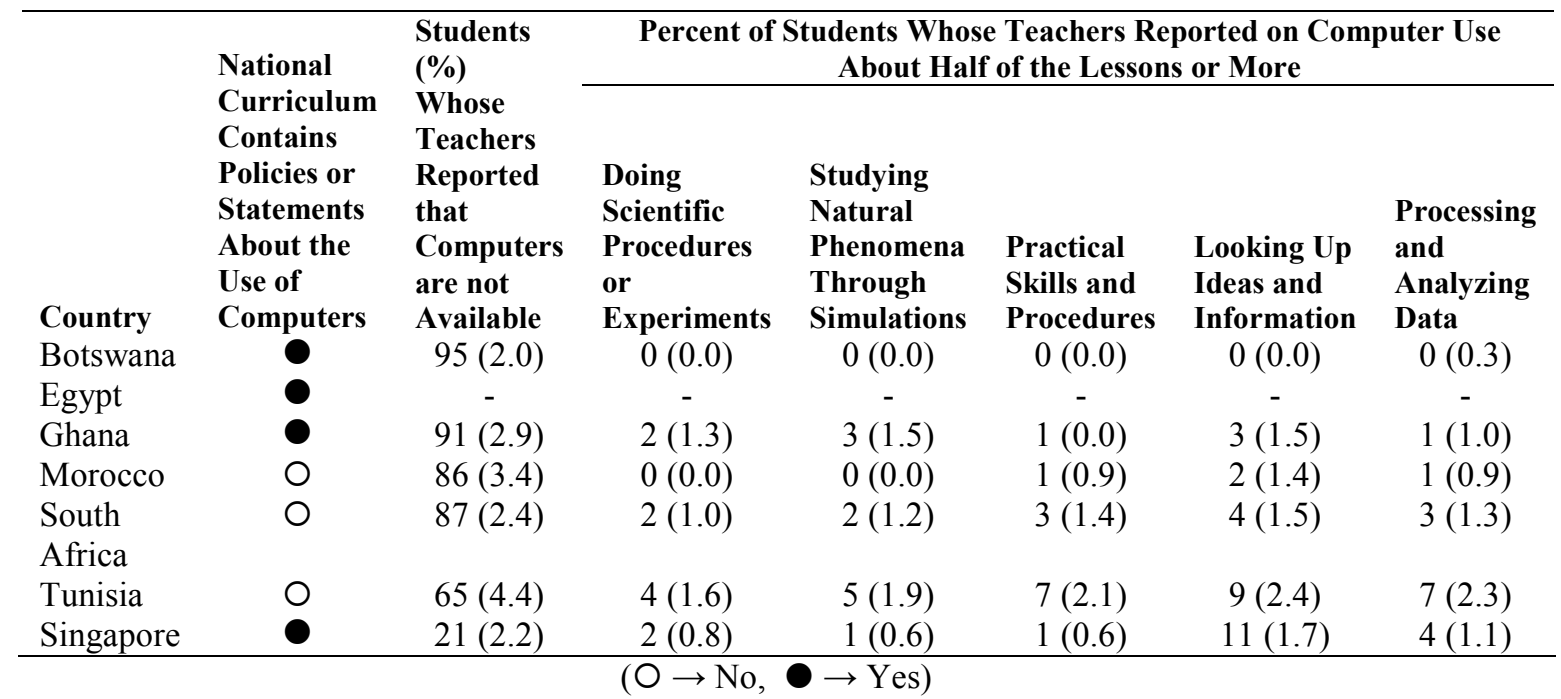

In fact, the African countries are among those that make the least use of the technology (i.e. calculators and computers) in their curricula. It was observed that students' performance in the two subjects were high in countries that were encouraging the use of the technology. Singapore, for example, where the best results were reported in both subjects, practices the use of technology.

Table 4. Use of calculators in mathematics class

\begin{tabular}{|c|c|c|c|c|c|c|}
\hline \multirow[b]{2}{*}{ Country } & \multirow{2}{*}{$\begin{array}{l}\text { National } \\
\text { Curriculum } \\
\text { Contains Policies } \\
\text { or Statements } \\
\text { About the Use of } \\
\text { Calculators }\end{array}$} & \multirow{2}{*}{$\begin{array}{l}\text { Students }(\%) \\
\text { Whose Teachers } \\
\text { Reported that } \\
\text { Calculators are } \\
\text { not Available }\end{array}$} & \multicolumn{4}{|c|}{$\begin{array}{l}\text { Percent of Students Whose Teachers Reported on } \\
\text { Calculator Use About Half of the Lessons or More }\end{array}$} \\
\hline & & & $\begin{array}{l}\text { Checking } \\
\text { Answers }\end{array}$ & $\begin{array}{l}\text { Doing } \\
\text { Routine } \\
\text { Computation }\end{array}$ & $\begin{array}{l}\text { Solving } \\
\text { Complex } \\
\text { Problems }\end{array}$ & $\begin{array}{l}\text { Exploring } \\
\text { Number } \\
\text { Concepts }\end{array}$ \\
\hline Botswana & 0 & $87(4.5)$ & $7(2.1)$ & $8(2.5)$ & $9(2.4)$ & $5(1.9)$ \\
\hline Egypt & 0 & $0(0.0)$ & $46(4.0)$ & $64(4.1)$ & $52(4.1)$ & $36(3.9)$ \\
\hline Ghana & 0 & $61(5.0)$ & $5(2.0)$ & $4(1.7)$ & $7(2.4)$ & $4(2.0)$ \\
\hline Morocco & 0 & $1(1.1)$ & $15(4.8)$ & $10(4.0)$ & $13(4.1)$ & $15(5.0)$ \\
\hline South & 0 & $6(1.8)$ & $21(3.3)$ & $18(2.5)$ & $32(3.4)$ & $23(3.1)$ \\
\hline \multicolumn{7}{|l|}{ Africa } \\
\hline Tunisia & 0 & $44(4.6)$ & $6(2.0)$ & $8(2.4)$ & $5(1.9)$ & $8(2.4)$ \\
\hline Singapore & 0 & $0(0.0)$ & $63(2.4)$ & $63(2.1)$ & $65(2.5)$ & $32(2.2)$ \\
\hline
\end{tabular}

\section{Summary, Conclusion and Recommendation}

The paper examined the performance of the African countries - Botswana, Egypt, Ghana Morocco, Tunisia, and South Africa - in TIMSS-2003. The authors' commitment to TIMSS2003 stems probably from their desire to propel African economies through the development and use of science, mathematics and technology. Though science and mathematics are key subjects in the school system, the intended, implemented and attained curricula in these subjects are plagued with problems on the continent. The results of TIMSS-2003 have not only shown that the African countries performed significantly lower than the international country mean and those in sub-Saharan Africa ranked lowest in the whole world, but also that the African countries are among those that make the least use of the technology in their science and mathematics curricula. There is therefore the need for African governments to pay attention to 
the teaching of science and mathematics in the primary and secondary schools. There is also the need to carry out an indebt examination to identify the dimensions of the problem for information that would be helpful in policy decisions to address the issue across the continent. To achieve this will require reliable and valid information obtained through systematic and collaborative research across nations.

\section{References}

Anamuah-Mensah, J., Mereku, D. K. and Asabere-Ameyaw, A. (2004). Ghanaian Junior Secondary School Students' Achievement in Mathematics and Science: Results from Ghana's participation in the 2003 Trends in International Mathematics and Science Study, Accra: Ministry of Education Youth and Sports.

Gonzalez, E. J., Galia, J. and Li, I. (2004). 'Scaling methods and procedures for the TIMSS2003 mathematics and science scales'. In Martin, M. O., Mullis, I. V. S. and Chrostowski, S. J. (eds.) TIMSS-2003 technical report. Chestnut Hill, MA: International Study Centre, Boston College.

Martin, M. O., Mullis, I. V. S., Gonzalez, E. J., and Chrostowski, S. J. (2004) TIMSS 2003 International Science Report: Findings from IEA's Trends in International Mathematics and Science Study at the Fourth and Eighth Grades, Chestnut Hill, MA: Boston College

Mullis, I. V. S., Martin, M. O., Gonzalez, E. J., and Chrostowski, S. J. (2004) TIMSS 2003 International Mathematics Report: Findings from IEA's Trends in International Mathematics and Science Study at the Fourth and Eighth Grades, Chestnut Hill, MA: Boston College

Robitaille, D. F. \& Garden, R. A. (Eds.) (1996). TIMSS Monograph no.2: Research questions and study design. Vancouver, BC: Pacific Educational Press. 